\title{
PERAN PENDIDIKAN AGAMA ISLAM DALAM MEMBENTUK AKHLAK KARIMAH SISWA DI ERA REVOLUSI INDUSTRI 4.0 DI MTS BANAT KUDUS
}

\author{
Nisaana 'Azzalatifa, Mu'awanah dan Maulina Istighfaroh \\ Pesantren Riset Al-Muhtada, Semarang \\ Jl. Kol. Hadijanto Nomor 117 Banaran Sekaran, Gunungpati, Semarang; \\ nisaana48@gmail.com
}

\begin{abstract}
4.0 industrial revolution era is characterized by the development of increasingly sophisticated technology, especially in the field of communication. These positive impacts are accompanied by negative impacts. One of the negative impacts is the erosion of the character of students. For this reason, an effort is needed to improve the character of students in the 4.0 industrial revolution era by taking advantage of the role of Islamic religious education. Thus, the authors are interested in examining the role of Islamic religious education in shaping the character of students in the 4.0 industrial revolution era. This research uses a qualitative research approach and is descriptive in nature. The research was carried out at MTs NU Banat Kudus on March 10, 2021 by interviewing one of the moral teachers named Ms. Deti, S.Pd., in this study Ms. Deti stated that Islamic religious education, especially moral education, played a very important role in shaping the character of the students in this 4.0 industrial revolution era. This role is carried out side by side between teachers and schools. The role of the teacher is to remind and provide examples for students to always behave
\end{abstract}

Keywords : morals, role, industrial revolution

Received: May 02, 2021; Accepted: November 30, 2021; Available online: November, 30, 2021 


\section{1. Pendahuluan}

Pendidikan merupakan usaha sadar dan terencana yang dilakukan oleh guru untuk mencapai kegiatan proses belajar di dalam kelas maupun di luar kelas untuk mengembangkan potensi peserta didik. Pendidikan dapat mengembangkan potensi masyarakat, mampu menumbuhkan kemauan, serta membangkitkan nafsu generasi bangsa untuk menggali berbagai potensi, dan mengembangkannya secara optimal bagi kepentingan pembangunan masyarakat secara utuh dan menyeluruh (Mulyasa dalam Tutuk, 2019: 220). Pendidikan dijadikan sebagai penyalur bakat yang ada pada peserta didik dalam mengembangkan potensi yang dimiliki peserta didik, baik potensi keagamaan, moral, karakter, dan bakatsehingga pendidikan di Indonesia menjadi pendidikan yang humanis sesuai dengan ajaran Islam.

Pendidikan agama islam merupakan salah satu isi yang mengupayakan para siswa untuk menggerakan perkembangan akhlak karimah siswa dalam menyikapi nilai. Dalam mengupayakan pendidikan nilai maka harus dilakukan dalam satu just school environment untuk mewujudkan keberhasilan pendidikan moral. Nilai-nilai tersebut diantaranyaadalah nilai kultural, yuridis formal, dan nilaireligius.Nilai kultural merupakan nilai yang berkaitan dengan budaya, karakteristik lingkungan sosial, dan masyarakat (Djhiri, 2002). Hal ini para siswa diharapkan mampu melihat nilai-nilai sosial kultural dengan cara mengembangkan keseimbangan yang sehat.Kemudian nilai yuridis formal berkaitan dengan politik, hukum, dan ideologi. Hal ini diharapkan nilai yang terkandung dalam nilai yuridis formal akan memberikan petunjuk kepada manusia untuk berpolitik dengan baik.Kemudian yang terakhiradalahnilai religius yang merupakan nilai yang sangat membedakan antara manusia dan mesin. Dimana nilai kemanusiaan tidak dimiliki oleh mesin, sebaliknya, mesin dapat dimiliki oleh manusia. Penanaman nilai ini yang perlu dimiliki siswa dalam memperkuat nilai karakter untuk menghadapi revolusi industri 4.0 (Dimas Indianto, 2019: 107).

Penelitian ini menggunakan objek berupa sekolah yang menggunakan kurikulum agama islam sehingga dapat diketahui peran pendidikan agama islam dalam pembentukan akhlak karimah siswa. Peneliti memilih Madrasah Tsanawiyah Banat Kudus sebagai objek penelitian, hal tersebut dikarenakan Madrasah Tsanawiyah Banat Kudus mempunyai keunggulan dan keunikan di bidang pendidikan agama islam dimana dalam proses pembelajarannya mengedepankan agama islam sebagai kurikulum belajar yang digunakan.

Berdasarkan latar belakang yang telah dipaparkan, peneliti tertarik untuk melakukan penelitian mengenai peran pendidikan agama islam dalam membentuk akhlak karimah siswa di era revolusi industri 4.0. di MTs NU Banat Kudus, untuk mengetahui peran serta implementasi pendidikan agama islam dalam membentuk akhlak karimah siswa di era revolusi industri 4.0. di MTs. Banat Kudus.

\subsection{Kajian Pustaka}

Peran pendidikan agama islam dalam membentuk akhlak karimah siswa telah menarik perhatian beberapa peneliti. Pertama, penelitian Puji (2015) yang berjudul "Peran Sekolah dalam Pembentukan Pendidikan Karakter di Era Revolusi Industri 4.0" menunjukkan bahwa Prinsip pembentukan pendidikan karakter di sekolah bisa dilakukan oleh satu pihak, akan tetapi seluruh pihak atau komponen yang ada di dalam sekolah baik 
itu kepala sekolah, guru, tenaga kependidikan, siswa maupun petugas kebersihan sekalipun. Perbedaan penelitian yang dilakukan Puji (2015) dengan penelitian ini terletak pada objek penelitian.Objek penelitian Puji (2015) yaitu pembentukan pendidikan karakter di Era revolusi industri, sedangkan pada penelitian ini objek penelitiannya berupa peran pendidikan agama islam dalam membentuk akhlak karimah siswa. Kedua, Penelitian Dimas Indianto (2019) yang berjudul "Pendidikan Agama Islam dalam Revolusi Industri 4.0" menunjukkan bahwa tantangan pada dunia pendidikan dalam menghadapi industri 4.0 adalah penanaman nilai-nilai pendidikan yang pelu dikembangkan. Perbedaan penelitian yang dilakukan Dimas Indianto (2019) dengan penelitian ini terletak pada objek penelitian. Objek penelitian Dimas Indianto (2019) yaitu Pendidikan Agama Islam dalam Revolusi Industri 4.0, sedangkan pada penelitian ini objek penelitiannya berupa peran pendidikan agama islam dalam membentuk akhlak karimah siswa. Ketiga, Penelitian Dian Arif (2019) yang berjudul "Tantangan Karakter Di Era Revolusi Industri 4.0 dalam Membentuk Kepribadian Muslim" menunjukkan bahwa karakter merupakan nilai-nilai perilaku manusia yang universal, mencakup "hablum minallah, hablum minannas dan hablum minal alam". Karakter tersalurkan mulai sejak dini/dalam kandungan hingga dewasa, melalui pikiran, sikap, perasaan, dan perbuatan. Perbedaan penelitian yang dilakukan Dian Arif (2019) dengan penelitian ini terletak pada objek penelitian. Objek penelitian Dian Arif (2019) yaitu Pendidikan Agama Islam dalam Revolusi Industri 4.0, sedangkan pada penelitian ini objek penelitiannya berupa peran pendidikan agama islam dalam membentuk akhlak karimah siswa. Pada penilitian sebelumnya membahas tantangan karakter di era revolusi industri 4.0, Pendidikan agama islam di era revolusi industri, dan peran sekolah dalam pembentukan pendidikan karakter di era revolusi industri. Pembaharuan pada penelitian yang kami teliti adalah kami menggali peran guru pendidikan agama islam dalam membentuk akhlak karimah siswa di era revolusi industri 4.0.

\subsection{Metode Penelitian}

Penelitian ini menggunakan pendekatan penelitian kualitatif dan bersifat deskriptif yang menggambarkan sebuah keadaan dengan apa adanya. Penelitian kualitatif merupakan penelitian yang dilakukan dengan menangkap fenomena-fenomena sosial yang ada dalam masyarakat dan kemudian dideskripsikan dengan kalimat.

Penelitian ini merupakan penelitian lapangan (field research). Oleh karena itu, teknik penelitian yang digunakan dalam penelitian ini adalah model wawancara, observasi, dan dokumentasi.

Adapun Teknik analisis data yang digunakan dalam penelitian ini adalah analisis data kualitatif. Pada ptahap analisis data, peneliti menggunakan model interactive model, dimana terdapat unsur-unsur yang terdiri dari reduksi data (data reduction), penyajian data (data display), dan conclutions drowing/verifiying. Alur teknik analisis data dapat dilihat seperti gambar di bawah ini.

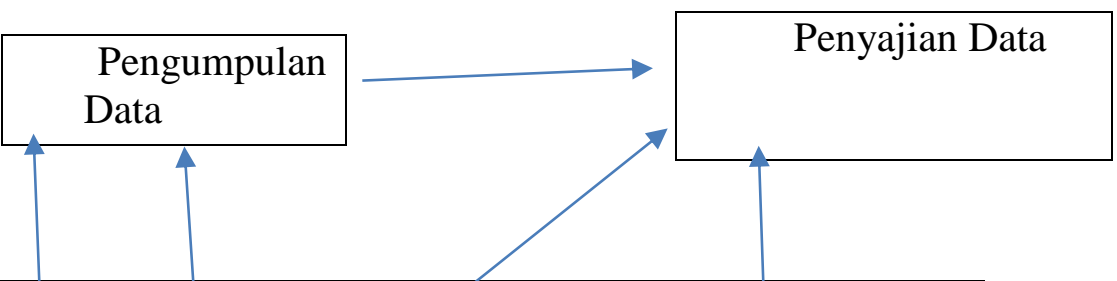

Al-Hikkmah: Jurnal Studi Agama-Agama/Vol. 7 , No. 2, 2021 


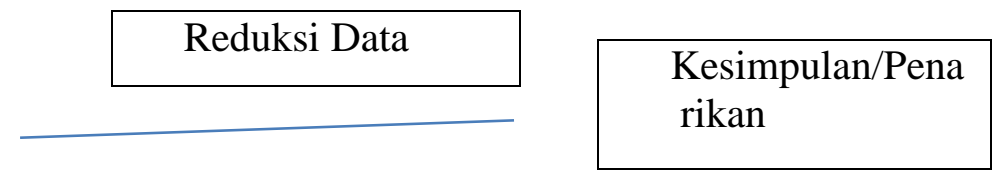

\subsection{Hasil dan Pembahasan}

\subsubsection{Sejarah Singkat Mts Banat Kudus}

Pada tanggal 2 Januari 1957, MTs NU Banat Kudus resmi didirikan oleh Yayasan Pendidikan Banat Kudus dengan akte notaris nomor: 45/81 yang diketuai oleh K.H. Masdain Amin. Penyelenggara MTs NU Banat Kudus yang didirikan oleh sekelompok Ulama dan tokoh masyarakat muslim di Kudus Jawa Tengah yang sadar dan menaruh perhatian terhadap keadaan dan perkembangan bidang pendidikan umat Islam dan bangsa Indonesia. Yayasan ini berdasarkan Pancasila berazazkan Islam Ala Ahlussunnah Waljamaah yang bertujuan untuk membangun dan memajukan masyarakat Indonesia terutama pelajar putri. Awal berdirinya MTs. Banat Kudus ini, wanita-wanita Islam dibekali pengetahuan Islam yang amali dan mampu memimpin wanita-wanita Islam untuk hidup maju bersama masyarakat yang lain, melangkah untuk memenuhi tuntutantuntutan yang zamani dan mampu berkompetisi positif dengan lembaga-lembaga lain yang siap melaksanakan program pengembangan baik fisik maupun non fisik.

\subsubsection{Gambaran Umum Lokasi Penelitian}

Lokasi penelitian dilaksanakan di MTs NU Banat Kudus beralamat di Jalan KHR Asnawi Nomor 30, Pejaten, Damaran, Kecamatan Kota Kudus, Kabupaten Kudus, Jawa Tengah. Batas MTs. Banat Kudus yaitu Sekolah Raudhatul Athfal (RA) Banat, NU Kudus, dan Madrasah Qudsiyyah, Selatan yaitu perempatan jember, sebelah timur menara kudus dan barat SMP dan SMA Muhammadiyah Kudus.

\subsubsection{Peran Pendidikan Agama Islam dalam Membentuk Akhlak Siswa di MTs Banat Kudus}

Dalam membentuk akhlak pasti butuh yang namamnya pendidikan akhlak. Karena dasar agama yang kuat akan membentuk akhlak yang kuat. Pendidikan akhlak ini bisa didapatkan di lembaga-lembaga sekolah. Sekolah merupakan lingkungan kedua sangat berperan penting dalam membina akhlak, baik mental, pengetahuan, dan keterampilan. Hal ini peran sekolah yang dapat memengaruhi akhlak siswa yang nantinya langsung berdampak pada pembelajaran dikelas. Sehingga tanggung jawab besar sekolah dan para guru pendidikan akhlak serta aparat sekolah untuk mewujudkan akhlak karimah siswa. Selain tiu, tentunya pembelajaran akhlak sangat efektif untuk membentuk akhlak karimah siswa karena dalam pembelajaran akhlak seperti dalam kitab ta'lim muta'alim itu 
dipelajari bagaimana tata krama terhadap guru, dll. Juga mengingat bahwa anak itu juga perlu dibimbing dan terus diingatkan, dan itu linear dengan proses pembelajaran akhlak.

Pembelajaran di dalam sekolah dapat meningkatkan kreativitas siswa dan menambah ilmu pengetahuan mereka sebagai kemampuan penguasaan materi. Akan tetapi, keberhasilan bukan dilihat dari nilai siswa, berdasarkan keterangan dari Ibu Deti, S.Pd bahwa nilai ujian mata pelajaran akhlak tidak ada pengaruhnya sama sekali dengan akhlak siswa. Bahkan ada seorang siswa yang nilainya bagus justru akhlaknya kurang baik begitu pun sebaliknya, siswa yang nilainya biasa saja justru akhlaknya bagus, sopan santun, patuh terhadap guru. Sehingga keberhasilan akhlak siswa tidak dapat diukur melalui seberapa nilai tertinggi siswa yang telah menguasai mata pelajaran. Hal ini disebabkan siswa suka meniru terhadap factor dilingkungannya. Hal inilah merupakan tantangan bagi guru akhlak di MTs Banat Kudus. Hal demikian itu, sikap yang suka meniru membuat guru MTs Banat Kudus menjadi sebuah tantangan tersendiri. Hal tersebut dikarenakan tidak semua hal yang ada di sekeliling anak tersebut adalah teman dan lingkungan yang baik. Apabila siswa salah meniru disekelilingnya maka tidak menutup kemungkinan mereka akan menyebabkan salah jalan.

Berdasarkan keterangan dari Ibu Deti, S.Pd selaku guru akhlak pun menyatakan bahwa peran sekolah dan guru sama-sama saling mendukung untuk membentuk siswasiswa yang tidak hanya unggul di bidang akademik, namun juga yang mar'atus shalihah. Untuk peran sekolah sendiri itu misalnya dengan membuat tata tertib yang harus ditaati oleh siswa sehingga siswa harus mentaati tata tertib tersebut dimana dengan mentaati tata tertib tersebut sama halnya dengan proses membiasakan siswa untuk melakukan akhlak karimah. Hal ini merupakan usaha sekolah dalam membina siswa untuk selalu berperilaku sesuai norma yang berlaku di dalam sekolah.

Namun, disaat pandemi covid-19 ada beberapa siswa yang tidak ikut pembelajaran dan ketidaktepatan dalam mengumpulkan tugas. Sehingga guru MTs. Banat Kudus berusaha untuk mengetahui apa penyebab permasalahan tersebut. Dari wawancara kami kepada beliau Ibu Guru Deti, S.Pd mengatakan bahwa untuk mencari solusinya yaitu langkah pertama adalah menyelidiki terlebih dahulu kondisi siswa yang menyebabkan ia berlaku tidak sesuai dengan akhlak karimah, biasanya siswa dipanggil terlebih dahulu oleh wali kelas, apabila wali kelas tidak berhasil mengatasi masalahnya, maka akan diserahkan ke guru BK. Di masa pandemic seperti ini, masalahnya biasanya adalah siswa tidak tepat waktu dalam mengumpulkan tugas. Untuk mengatasi masalah tersebut, wali kelas akan menghubungi siswa tersebut secara pribadi untuk ditanyai apa masalahnya.

Peran sekolah harus mampu menjalin hubungan kerja sama antara guru dan wali murid siswa, hal ini dikarenakan untuk menanggulangi penimpangan-penyimpangan akhlak siswa di era revolusi industry 4.0. yang nantinya dapat diiplementasikan di dalam kehidupan sehari-hari. Oleh karena itu, dalam keadaan pandemi covid-19 ini orang tua lah yang akan selalu mendampingi siswa saat pembelajaran daring. Mengingat guru tidak 
dapat mengawasi siswa secara langsung. Meskipun, pembelajaran daring atau online peran guru di sekolah di MTs Banat Kudus untuk membentuk akhlak siswa saat pembelajaran daring ini tetap dipantau.

Dalam pemantauan yang demikian, maka guru harus menggunakan strategi agar bisa mencapai sasaran target. Definisi dari strategi merupakan usaha untuk mencapai sasaran tertentu dengan berbagai tindakan yang telah direncanakan. Sehingga strategi yang digunakan guru akhlak Mts Banat Kudus yaitu sesuai dengan beliau yang ajarkan di kitab ta'lim tentang perilaku yaitu dengan memerintahkan siswa hafalan ta'dimil ustad yang ada nadzomnya. Diharapkan siswa mampu untuk memahami isi dari nadzom kitab tersebut lalu diimplementasikan dalam kehidupan sehari-hari.

\subsubsection{Implementasi Pendidikan Agama Islam dalam Membentuk Akhlak} Siswa di Era Revolusi Industri di MTs Banat Kudus

MTs NU Banat Kudus mengimplementasikan Pendidikan agama islam khususnya pelajaran akhlak dalam rangka membentuk akhlak karimah siswa dilakukan dengan membuat berbagai peraturan yang diharapkan dapat ditaati oleh seluruh siswa. Peraturan-peraturan tersebut dibuat dengan tujuan untuk membiasakan siswa berperilaku sesuai akhlak karimah dalam kehidupan sehari-hari. Hal tersebut dikatakan oleh salah satu guru akhlak di MTs NU Banat Kudus, yairu Ibu Deti bahwa sekolah punya peraturan yang harus ditaati oleh siswa. Tidak hanya sekolah yang punya aturan, tetapi di setiap pelajaran pun ada peraturannya tersendiri. Karena pada era revolusi industri seperti ini, anak-anak sudah mengenal media sosial, maka jelas hal tersebut berpengaruh terhadap akhlaknya. Sehingga disini juga setiap guru harus selalu mengingatkan anak untuk ber-unggahungguh kepada guru.

Sebagai contoh implementasi dari akhlak siswa MTs. Banat Kudus para guru yaitu antara lain sebagai berikut.

1. siswa bersalaman ketika bertemu guru

Hal ini siswa MTs Banat Kudus dibudayakan untuk selalu bersalaman ketika bearada di lingkungan sekolah. Karena tidak menutup kemungkinan era revolusi industry 4.0 siswa akan terkena dampak dari adanya sikap kurang patuh. Salah satu budaya ini maka dapat dijadikan contoh dalam rangka menyambung silatuhrami antara murid dan guru.

2. Siswa Tidak makan sambil berjalan

Pembiasaan adab tidak makan sambil jalan merupakan hal yang terpuji. Sudah seharusnya siswa harus membiasakan adab guna membentuk akhlak karimah di era revolusi industry 4.0. Untuk menumbuhkan pembiasaan akhlak yang demikian itu, maka pendidikan akhlak pun harus dilakukan secara intesif.

3. Menghormati guru ketika pembelajaran langsung

Pernyataan ini maksudnya yaitu ketika pembelajaran berlangsung maka seorang siswa harus mendengarnya dengan baik. Hal ini harus dibiasakan supaya siswa MTs. Banat Kudus jiwanya dapat tertanam rasa hormat terhadap guru ketika di kelas.

Al-Hikkmah: Jurnal Studi Agama-Agama/Vol. 7 , No. 2, 2021 
Tak hanya itu, di dalam pembelajaran berlangsung siswa diberikan contoh konkrit seperti dengan diberikan contoh nyata berakhlakul karimah oleh para guru, para siswa juga diberikan contoh tokoh-tokoh cendekiawan muslim yang ada di kitab ta'lim muta'alim. Guru mata pelajaran ta'lim seringkali menceritakan kisah-kisah sukses par cendekiawan tersebut disertai dengan akhlak karimah para tokoh tersebut. Metode bercerita ini dirasa efektif untuk memberikan motivasi kepada siswa untuk selalu berakhlakul karimah dalam kehidupan sehari-hari. Seperti sifat anak usia MTs yang masih suka meniru, metode bercerita ini akan menjadikan siswa meniru sikap dari tokoh yang disukainya.

Hal ini ketika usia remaja mulai meniru maka para guru MTs Banat Kudus selalu memberikan contoh tokoh yang dapat memotivasi atau menginspirasi mereka supaya dapat menirunya tokohnya. Pada pembelajaran akhlak di kitab ta'lim muta'alim banyak diberikan contoh tokoh-tokoh yang sukses dibidangnya dan tentunya dengan akhlak karimah yang tokoh-tokoh tersebut miliki. Dengan memaparkan tokoh-tokoh yang bisa menginspirasi mereka, biasanya anak-anak akan meniru sikap-sikap tokoh tersbut.

Untuk meningkatkan akhlak siswa, lembaga sekolah MTs. Banat Kudus tetap menjalankan berbagai metode pembelajaran. Bahwasannya membiasakan akhlak yang terpuji dapat meminimalisir penyimpangan-penyimpangan yang mungjkn saja terjadi. Karenanya untuk mencapai tujuan, maka metode pengajaran tersebut dirasa tepat. Mengingat ada beberapa siswa MTs Banat Kudus yang akhlaknya masih kurang baik. Diharapkan dengan mengajar melalui dari berbagai metode siswa mampu untuk menerapkan di dalam kehidupannya sehari-hari. selain itu, diharapkan siswa semangat belajar dalam kegiatan proses belajar mengajar.

Selain itu, para guru di MTs NU Banat Kudus juga meyakini bahwa anak usia MTs itu masanya meniru. Oleh karena itu, para guru di MTs NU Banat Kudus juga selalu memberikan contoh bagaimana berakhlakul karimah dalam kehidupan sehari-hari dan juga ikut konsisten untuk memberikan tauladan bagi siswa MTs. Banat Kudus. Diharapkan peserta didik dapat meniru dan mengikuti apa yang mereka lihat dari seorang guru. Karena keteladanan guru ssangat berpengaruh terhadap siswa MTs Banat Kudus. Keteladan guru itulah yang mempunyai nilai tinggi, meskupun ada beberapa bagian mereka akhlaknya kian menipis. Akhlak ini harus direalisasikan dalam kehidupan seharihari terutama di lingkungan sekolah. Supaya peran pendidikan agama ini berhasil dan mencapai tujuan pendidikan dan mampu dalam menjalankan kewajibannya sebagai siswa.

\subsection{Kesimpulan}

Berdasarkan pembahasan di a tas, maka dapat disimpulkan bahwa Pertama, terkait dengan peran sekolah dalam membentuk akhlak karimah siswa di era revolusi industri 4.0 di MTs NU Banat Kudus, hasil penelitian menyatakan bahwa sekolah yang merupakan lingkungan kedua bagi para siswa dirasa sangat berperan penting dalam membina akhlak,

Al-Hikkmah: Jurnal Studi Agama-Agama/Vol. 7 , No. 2, 2021 
baik mental, pengetahuan, dan keterampilan. Namun, untuk membentuk akhlak siswa bukan hanya peran sekolah saja, melainkan guru pun turut mewujudkan terciptanya akhlakul karimah siswa. Hal tersebut sejalan dengan apa yang dikatakan oleh salah satu guru akhlak, bahwa peran sekolah dan guru sama-sama saling mendukung untuk membentuk siswa-siswa yang tidak hanya unggul di bidang akademik, namun juga yang mar'atus shalihah. Untuk peran sekolah sendiri itu misalnya dengan membuat tata tertib yang harus ditaati oleh siswa sehingga siswa harus mentaati tata tertib tersebut dimana dengan mentaati tata tertib tersebut sama halnya dengan proses membiasakan siswa untuk melakukan akhlak karimah.

Kemudian untuk peran guru sendiri adalah dengan selalu mengingatkan dan memberikan contoh kepara siswa untuk selalu berperilaku sesuai dengan akhlakul karimah. Namun, di masa pandemi seperti ini peran guru untuk membentuk akhlakul karimah siswa sedikit terkendala karena sistem pembelajaran daring yang membuat guru kurang dalam memantau para siswanya. Strategi guru akhlak untuk menaggulangi masalah tersebut adalah dengan selalu mengingatkan para siswanya setiap sebelum memulai pembelajaran daring untuk selalu berakhlakul karimah.

Kedua, terkait implementasi pendidikan agama islam khususnya pelajaran akhlak dalam membentuk akhlak karimah siswa tentunya sangat banyak. MTs NU Banat Kudus mengimplementasikan Pendidikan agama islam khususnya pelajaran akhlak dalam rangka membentuk akhlak karimah siswa dilakukan dengan membuat berbagai peraturan yang diharapkan dapat ditaati oleh seluruh siswa. Peraturan-peraturan tersebut dibuat dengan tujuan untuk membiasakan siswa berperilaku sesuai akhlak karimah dalam kehidupan sehari-hari. Selain dengan membuat berbagi peraturan untuk membentuk akhlak karimah siswa, guru di MTs NU Banat Kudus memiliki dua strategi khusus yaitu strategi mencontoh dan bercerita. Strategi mencontoh ini dilakukan dengan cara guru selalu memberikan contoh berperilaku sesuai akhlak karimah dalam kehidupan sehari-hari. Sedangkan strategi bercerita ini dilakukan dengan cara guru memceritakan kisah-kisah sukses para tokoh cendekiawan muslim yang tentunya memiliki akhlak karimah yang baik.

\section{Referensi}

Dimas, Indianto. 2019. Pendidikan Agama Islam dalam Revolusi Industri 4.0. Prosiding Seminar Nasinal: Universitas Muhammadiyah Purwokerto.

Nugraha, Puji. 2015. Peran Sekolah dalam Pembentukan karakter di Era Revolusi Industri.Prosiding Konferensi Pendidikan Nasional. 
Pratama, Dian Arif Noor. 2019. Tantangan Karakter di Era Revolusi Industri 4.0 dalam Membentuk Kepribadian Muslim. Jurnal Manajemen Pendidikan Islam. Vol 3 No 1. UIN Sunan Kalijaga.

Ningsih, Tutuk. 2019. Peran pendidikan islam dalam membentuk karakter siswa di era revolusi industri 4.0 di Madrasah Tsanawiyah Negeri 1 Banyumas. Insania jurnal pemikiran alternative kependidikan. 24 (2):220

https://jateng.kemenag.go.id/warta/opini/detail/budaya-bersalaman (diakses pada tanggal 23 maret 2021) 